\title{
3-Hydroxypropionaldehyde Applications and perspectives of biotechnological production
}

\section{Journal Article}

\section{Author(s):}

Vollenweider, S.; Lacroix, C.

Publication date:

2004-03

Permanent link:

https://doi.org/10.3929/ethz-b-000051119

\section{Rights / license:}

In Copyright - Non-Commercial Use Permitted

\section{Originally published in:}

Applied Microbiology and Biotechnology 64(1), https://doi.org/10.1007/s00253-003-1497-y 


\section{3-Hydroxypropionaldehyde: applications and perspectives of biotechnological production}

Received: 17 July 2003 / Revised: 20 October 2003 / Published online: 11 December 2003

C) Springer-Verlag 2003

\begin{abstract}
Hydroxypropionaldehyde (3-HPA) forms, together with HPA-hydrate and HPA-dimer, a dynamic, multi-component system (HPA system) used in food preservation, as a precursor for many modern chemicals such as acrolein, acrylic acid, and 1,3-propanediol (1,3PDO), and for polymer production. 3-HPA can be obtained both through traditional chemistry and bacterial fermentation. To date, 3-HPA has been produced from petrochemical resources as an intermediate in 1,3-PDO production. In vivo, glycerol is converted in one enzymatic step into 3-HPA. The 3-HPA-producing Lactobacillus reuteri is used as a probiotic in the health care of humans and animals. The biotechnological production of 3-HPA from renewable resources is desirable both for use of 3-HPA in foods and for the production of bulk chemicals. The main challenge will be the efficient production and recovery of pure 3-HPA.
\end{abstract}

\section{Elucidation of the HPA system}

The very first observation leading eventually to the elucidation of the synthesis pathway of 3-hydroxypropionaldehyde (3-HPA) dates back to as early as 1741 . Geoffrey (1742) described that a new water-soluble syrup was formed from fat after saponification. In 1779, Scheele isolated the same syrup from a diverse array of substrates, including almonds, linseed, rape oils, olive oil, butter and lard. Because of its sweet taste he named it "Ölsüss" (see Scheele 1931). About 40 years later, the French pioneer of organic chemistry Chevreul noted that, after saponification, the neutral fats were transformed into solid fatty acids and the sweet component of Scheele. He renamed this

\footnotetext{
S. Vollenweider $(\bowtie) \cdot C$. Lacroix

Laboratory of Food Biotechnology, Institute of Food Science and Nutrition, Swiss Federal Institute of Technology, 8092 Zurich, Switzerland

e-mail: sabine.vollenweider@ilw.agrl.ethz.ch

Tel.: +41-1-6325369

Fax: +41-1-6321156
}

liquid, believed to be an alcohol, glycerine (Chevreul 1823; Matagrin 1925).

Chevreul's discoveries had some very practical implications for everyday life. The removal of glycerol from the raw material of candles both greatly increased their hardness and illuminating power, and eliminated the unpleasant odour of burning candles that resulted from glycerol decomposition (Matagrin 1925). Brandes was the first to describe this decomposition product and name it acrolein, thus reflecting both its smell (acris) and consistency (oleum), whereas Berzelius was the first to identify it as an aldehyde (Berzelius 1839). Meanwhile, in Liebig's laboratory, Redtenbacher noted that acrolein was formed by the combustion of fats, but not of fatty acids. Furthermore, he suspected that glycerol could be the source of acrolein. During the distillation of glycerol he obtained acrolein, and confirmed that it is an aldehyde since upon further oxidation it formed a new acid, which he named acrylic acid. Thus, Redtenbacher established that acrolein can be formed from glycerol through the loss of four molecules of water (Redtenbacher 1843).

Some years later, Nef heated acrolein in the presence of water, which resulted in the formation of hydracrylaldehyde, or 3-HPA (Fig. 1); this was the first formal description of the compound (Nef 1904). The kinetics of acrolein hydration and the formation of 3-HPA were studied later (Pressman and Lucas 1942). Redtenbacher established that not only chemical, but also biological reactions could use glycerol as a "substrate", he described the formation of propionic acid from glycerol by bacterial fermentation (Redtenbacher 1846), and Pasteur discovered that glycerol could also be formed during alcoholic fermentation (Pasteur 1858a, 1858b). A few years later, Napoleon asked Pasteur to study the origin of different types of wine spoilage, referred to as "les maladies de l'amertume des vins". During this period, France produced about 50 million hectolitres of wine worth about 500 million Francs annually, thus making the wine industry the most profitable economic sector in France. Considerable losses from different plant diseases, as well as from wine spoilage itself, prompted this research. 
Pasteur found that bacteria were responsible for the formation of bitter tastes in wine leading to its spoilage (Pasteur 1866).

However, only after 1910 was the connection made between the formation of acrolein from glycerol by bacterial fermentation and the spoilage of wine (Voisenet 1910). Moreover, Voisenet found that propanolal, now referred to as 3-HPA, is formed as an intermediate in this synthesis pathway (Fig. 1). He also identified trimethylene glycol [1,3-propanediol (1,3-PDO)] as another product of this fermentation process (Voisenet 1910, 1914a, 1914b) (Fig. 1). Although Voisenet could identify the presence of acrolein and 3-HPA by a colorimetric test, it was only in 1945 that a quantitative test using tryptophan was developed for acrolein (Circle et al. 1945). The same test was later used to determine the concentration of 3HPA.

In 1950, during the first systematic study of 3-HPA by Hall and Stern, the importance of 3-HPA as an intermediate of great potential value in the solvent or plasticiser field was mentioned. In their work, Hall and Stern described a dimeric form of 3-HPA in equilibrium with the monomeric form commonly found in solution (Hall and Stern 1950). Finally in 1981, using NMR, Nielsen et al. were able to identify HPA-hydrate as the last component of the HPA system. In summary, the work of over 100 years of research outlined above has resulted in the formulation of a complex reaction model in which 3-HPA plays a central role (Fig. 1). In vivo, 3-HPA is produced by dehydration of glycerol by a $\mathrm{B}_{12}$-dependent glycerol dehydratase, and further reduced to $1,3-\mathrm{PDO}$ by an $\mathrm{NAD}^{+}$-dependent oxidoreductase (Toraya 2000). In aqueous solution, 3-HPA undergoes reversible dimerisation and hydration, thus resulting in an equilibrium of 3-HPA, HPA-hydrate, and HPA-dimer, referred to here as HPA or the HPA-system. During thermal dehydration, acrolein is formed in HPA-containing solutions (Fig. 1). Detailed descriptions for the enzymatic pathway are given by Biebl et al. (1999) and Lüthi-Peng et al. (2002a), and a detailed description of acrolein formation is given by Hall and Stern (1950) and Nielsen et al. (1981).

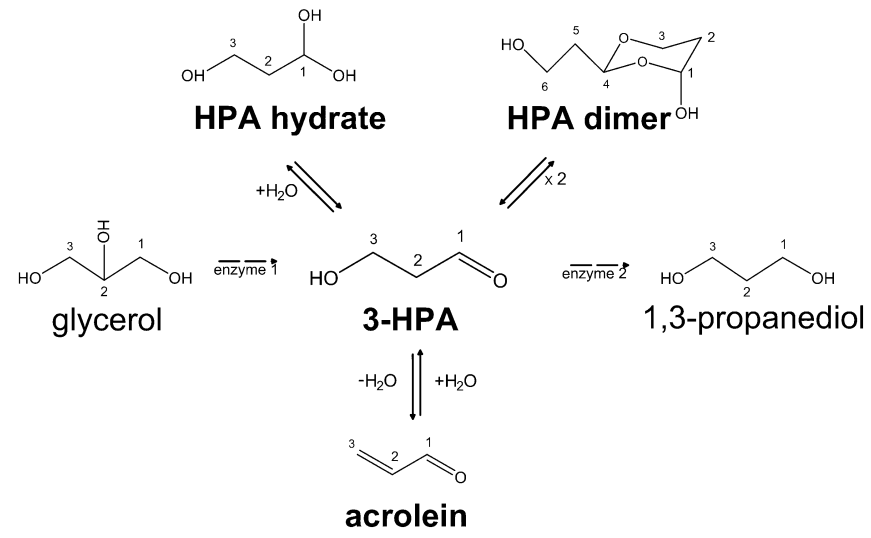

Fig. 1 Formation of hydroxypropionaldehyde (HPA), 1,3-propanediol (1,3-PDO), and acrolein. $\rightarrow$ Enzymatic reaction; $\rightleftarrows$ equilibrium reactions; enzyme 1 glycerol dehydratase; enzyme 2 1,3 propanediol oxidoreductase
As illustrated by this historical outline, many components of the HPA system can be obtained both through traditional chemistry and bacterial fermentation (Mickelson and Werkman 1940; Otsuka 2003; Sobolov and Smiley 1960). The current use and future prospects of the HPA system in modern biotechnology, in particular as an alternative to its production from fossil resources by the petrochemical industry, will be discussed below.

\section{Production of 3-HPA}

\section{Petrochemically derived 3-HPA}

The raw materials for the multistep synthesis are obtained from the petrochemical industry. Two chemical processes are known to produce 3-HPA as an intermediate in 1,3PDO production: the Degussa and Shell processes. The Degussa process begins with the catalytic transformation of propylene into acrolein, which is hydrated to 3-HPA and further reduced to 1,3-PDO (Arntz and Wiegand 1991; Brossmer and Arntz 2000). Although propylene is inexpensive, the separation of the different molecules is expensive and acrolein is toxic. The 1,3-PDO yield of this process is only $43 \%$. The Shell process begins with ethylene, forming ethylene oxide, which is transformed by a hydroformylation reaction under high pressure (150 bar) with syngas to 3-HPA (Knifton et al. 2003). Ethylene is inexpensive and the intermediate products are not toxic, but 3-HPA has to be extracted from the organic phase. The $1,3-\mathrm{PDO}$ yield is about $80 \%$. No information on the yields for 3-HPA production is available in the literature.

\section{3-HPA from renewable resources}

Biotechnological production has several advantages compared to the chemical process. First, 3-HPA production can be carried out in glycerol-containing aqueous solution at room temperature or at $37^{\circ} \mathrm{C}$ under normal pressure. The transformation from glycerol to 3-HPA is a one-step enzymatic catalysis (Fig. 1) and the yields (85-87\% mol 3$\mathrm{HPA} / \mathrm{mol}$ glycerol) have been shown to be higher than those achieved by chemical synthesis (Arntz and Wiegand 1991; Brossmer and Arntz 2000; Ulmer et al. 2002; Vollenweider et al. 2003).

To date, six genera of bacteria that are able to ferment glycerol into 3-HPA have been identified: Bacillus (Voisenet 1914a); Klebsiella (Aerobacter) (Abeles et al. 1960; Reymolds et al. 1939; Slininger et al. 1983); Citrobacter (Mickelson and Werkman 1940); Enterobacter (Barbirato et al. 1996); Clostridium (Humphreys 1924); and Lactobacillus (Mills et al. 1954; Serjak et al. 1954). The enzyme responsible for the formation of 3HPA from glycerol, glycerol dehydratase, is known to be cobamide-dependent (Abeles et al. 1960; Smiley and Sobolov 1962; Sobolov and Smiley 1960; Toraya 2000). 3 -HPA is normally an intracellular intermediate that does not accumulate but is reduced by an $\mathrm{NAD}^{+}$-dependent 
oxidoreductase to 1,3-PDO, the end-product of glycerol fermentation (Biebl et al. 1999; Daniel et al. 1999; Thiman 1955; Voisenet 1914b; Zeng and Biebl 2002).

The regulation of this pathway is dependent on the availability of fermentable carbohydrates, in particular glucose. In fact, the presence of glycerol and its transformation into 1,3-PDO enables the cells to recover the $\mathrm{NAD}^{+}$used during glycolysis. Under conditions of unlimited glucose, 1,3-PDO will be formed. With enterobacteria, the presence of glucose will therefore reduce the yield of 3-HPA production. With lactobacilli, a molar ratio of glucose to glycerol no greater than 0.33 will favour the accumulation of 3-HPA. In non-growing medium $\left(\mathrm{H}_{2} \mathrm{O}\right)$, addition of glucose reduces accumulation of 3-HPA. Therefore, biotechnological production of 3HPA should be performed without glucose, to favour accumulation of 3-HPA (El-Ziney et al. 1998; Lüthi-Peng et al. 2002a; Mills et al. 1954; Sauvageot et al. 2000; Sobolov and Smiley 1960). At high concentrations 3-HPA is secreted into the medium and can easily be concentrated by lyophylisation (Slininger et al. 1983; Talarico and Dobrogosz 1989; Vollenweider et al. 2003). However, the toxicity of 3-HPA towards bacteria limits the accumulation of this compound in the fermentation broth medium (Table 1, studies 1-5).

Two methods have been attempted to overcome this toxicity and increase the yield for biotechnological production. In the first method, 3-HPA is entrapped by semicarbazide (Ulmer et al. 2002), such that 3-HPA becomes unavailable. This reduces its toxic affect and prevents its further reduction to $1,3-\mathrm{PDO}$, increasing the yield of 3-HPA production. This method resulted in a very high total production of $621 \mathrm{mM} 3-\mathrm{HPA}$ (Table 1, studies 6-8). Although this method is very promising, the recovery of 3-HPA has never been reported. The second method uses Lactobacillus reuteri, a species shown to sustain large amounts of 3-HPA (Table 1, studies 9-10) produced from glycerol. However, although $L$. reuteri is very resistant to high concentrations of 3-HPA, its viability does decrease when 3-HPA is produced in large quantities.
To further optimise biotechnological production, bacterial strains that are both more efficient and capable of tolerating large amounts of 3-HPA need to be developed. To increase efficiency, undesirable by-product formation should be prevented. Genetic engineering of bacterial strains might be necessary, as was carried out in some studies to increase the yield of 1,3-PDO production (Zeng and Biebl 2002; Cameron et al. 1998). Two enzymatic targets appear to be of interest to increase the accumulation of 3-HPA. First, the elimination of 1,3-PDO oxidoreductase activity, which prevents the formation of 1,3PDO (Fig. 1); and second, the elimination of glycerol dehydrogenase (GDH), which forms dihydroxyacetone in a side reaction (Zeng and Biebl 2002). The development of bacterial strains capable of transforming glycerol into 3HPA via a non-cobamide-dependent glycerol dehydratase activity also deserves further development (Zeng and Biebl 2002).

To decrease the inhibitory effect of accumulating 3HPA, the use of semicarbazide to entrap 3-HPA (Vancauwenberge et al. 1990) warrants further development, in particular, development of a method to recover the 3-HPA. The use of semicarbazide for entrapment would have several advantages. For example, when 3-HPA is in its semicarbazone form, its inhibitory effect on cells is reduced, and there is no need to eliminate 1,3-PDO oxidoreductase activity because the substrate is not available. The recovery of 3-HPA from semicarbazide could also be developed as a purification step. Physical methods for 3-HPA purification such as distillation have proved difficult because of the high distillation point of HPA in a concentrated form and the formation of resins (Hall and Stern 1950; Stepanow and Schtschukin 1927).
Table 1 Biotechnological production of 3-hydroxypropionaldehyde (3-HPA) and 1,3-propanediol (PDO) from glycerol under different conditions

\footnotetext{
${ }^{\text {a}}$ Present

bot determined

${ }^{\mathrm{c}}$ Production in buffered semicarbazide

${ }^{\mathrm{d}}$ Production in water
}

\begin{tabular}{|c|c|c|c|c|c|c|}
\hline Study & Strain & $\begin{array}{l}\text { Glycerol } \\
(\mathrm{mM})\end{array}$ & $\begin{array}{l}\text { 3-HPA } \\
(\mathrm{mM})\end{array}$ & $\begin{array}{l}\text { PDO } \\
(\mathrm{mM})\end{array}$ & Strain & Reference \\
\hline 1 & Lactobacillus sp. & 2.34 & $+^{\mathrm{a}}$ & 2 & NRRL B-1720 & Sobolov and Smiley 1960 \\
\hline 2 & Lactobacillus sp. & 326 & 95 & $n d^{b}$ & NRRL B-1720 & Slininger et al. 1983 \\
\hline 3 & Enterobacter agglomerans & $\begin{array}{l}725 \\
830\end{array}$ & 30 & 237 & CNCM1210 & Barbirato et al. 1996 \\
\hline 4 & Citrobacter freudii & $\begin{array}{l}760 \\
740\end{array}$ & 17 & 400 & ATCC 8090 & \\
\hline 5 & Klebsiella pneumonia & $\begin{array}{l}760 \\
780\end{array}$ & 24 & 429 & ATCC 25955 & \\
\hline 6 & K. pneumonia & 333 & $177^{\mathrm{c}}$ & nd & ATCC 8724 & Slininger et al. 1983 \\
\hline 7 & K. pneumonia & 326 & $220^{\mathrm{c}}$ & nd & ATCC 8724 & Slininger and Bothast 1985 \\
\hline 8 & K. pneumonia & 760 & $621^{\mathrm{c}}$ & nd & ATCC 8724 & Vancauwenberge et al. 1990 \\
\hline 9 & Lactobacillus reuteri & 250 & 140 & 50 & 1063 & Talarico et al. 1988 \\
\hline 10 & L. reuteri & 200 & $170^{\mathrm{d}}$ & nd & ATCC 53608 & $\begin{array}{l}\text { Lüthi-Peng et al. 2002b; } \\
\text { Vollenweider et al. } 2003\end{array}$ \\
\hline
\end{tabular}




\section{Biotechnological applications}

\section{L. reuteri}

Probiotics are live microbial feed supplements, which beneficially affect the host by improving its intestinal microbial balance (Tannock 1999). They can inhibit pathogenic bacteria due to the production of antimicrobial compounds. Axelsson et al. (1988) were the first to report an antimicrobial compound produced by $L$. reuteri, a bacterial strain known to inhabit the gastrointestinal tract of all vertebrates and mammals (Casas and Dobrogosz 2000). The antimicrobial agent was described as an antifungal, anti-parasite, anti-viral and anti-cancer agent as well as an antibacterial agent (Dobrogosz and Lindgren 1988; Dobrogosz et al. 1989) and named reuterin, after the producing strain. Reuterin has a broad spectrum of antimicrobial activity against prokaryotes (both $\mathrm{Gram}^{+}$ and Gram $^{-}$) and eukaryotes (Saccharomyces cerevisiae and Trypanosoma cruzi). Further characterisation of reuterin revealed the presence of 3-HPA, HPA-hydrate, and HPA-dimer (Axelsson et al. 1988; Talarico and Dobrogosz 1989). Today the name reuterin is used as a synonym for the HPA system, mostly in the field of food preservation and health care.

A detailed review validating the use of $L$. reuteri as a probiotic has been published (Casas and Dobrogosz 2000), and the company, BioGaia, established a web-site on this topic (http://www.reuteri.com). Some of this information is summarised below. L. reuteri has been shown to survive the effects of gastric acid and bile salts in the stomach and upper intestine; bind to the gut mucus and epithelial cells; and to colonise the intestine. L. reuteri is expected to reduce the risk of diarrhoea among children and can significantly lower the incidence of watery diarrhoea among children suffering from rotavirus diarrhoea. It may also reduce Helicobacter pylori infections (Mukai et al. 2002; Shornikova et al. 1997). Finally, trials have shown that $L$. reuteri has a positive influence on the development of ileal tissue, thereby enhancing absorption of nutrients. Safety studies have been conducted on healthy newborns, small children, adults and immunodeficient adults (HIV positive) (Wolf et al. 1995, 1998). In all studies, L. reuteri has been shown to be free from side effects, even when administered in doses largely exceeding the levels normally contained in products containing $L$. reuteri (Casas and Dobrogosz 1997); a few individuals experienced a temporary increase in flatulence.

In animal studies, a cholesterol-lowering effect and significant strengthening of the immune defence have also been documented. With animals raised for meat production, administration of $L$. reuteri to newly hatched/ newborn animals led to better feed utilisation and growth than in the control groups. Sickness and mortality rates were also lower. Additionally L. reuteri has been shown to modulate immune responses in a series of animal models; such immuno-modulation may be one of the basic mechanisms by which $L$. reuteri exerts its probiotic effects in man (Valeur et al. 2002). In conclusion, supplementing food products such as tablets and milk products with $L$. reuteri, the only species shown to accumulate high amounts of 3-HPA in vitro, potentially offers a wide range of benefits to the consumer (Klantschitsch et al. 1996; Reid 1999). However, it is not yet known whether reuterin production occurs in vivo, and if this production is responsible for the health effects of $L$. reuteri. BioGaia is currently the main producer and sells $L$. reuteri-containing products through licensed partners worldwide (Table 2).

\section{HPA system as the antibiotic reuterin}

Biotechnologically produced HPA could be used to protect food against microbial spoilage. The anti-bacterial activity of reuterin has been shown to inhibit the growth of Listeria monocytogenes and Escherichia coli O157:H7 in meat products, milk and cottage cheese (Table 3).

For health care or pharmaceutical applications, reuterin has also been shown to be a useful agent in the sterilisation and fixation of biological tissues. Indeed, the use of reuterin for fixation is more efficient than using glutaraldehyde, and is less cytotoxic (Table 3). Treatment of Trypanosoma brucei brucei-infected mice with reuterin for 7 days led to a $61 \%$ reduction in bacterial numbers and to an increased survival of the mice (Table 3 ). HPA can therefore be described as a potent agent that shows
Table 2 Use of $L$. reuteri as a probiotic in different countries

\begin{tabular}{|c|c|c|}
\hline Country & Company & Products \\
\hline Sweden & BioGaia AB & $\begin{array}{l}\text { Tablets, capsules, powder and infant } \\
\text { formula; milk, yogurt, juice, fresh cheese } \\
\text { and ice-cream }\end{array}$ \\
\hline Finland & Ingman Foods $\mathrm{Oy} \mathrm{Ab}$ & $\begin{array}{l}\text { Yoghurts, fermented milks, cottage cheese, } \\
\text { ice-cream, and fruit drinks }\end{array}$ \\
\hline Great Britain & Farm Produce Marketing Ltd. & Yogurt drink \\
\hline Japan & $\begin{array}{l}\text { Chichiyasu milk products } \\
\text { company Ltd. }\end{array}$ & Milk products \\
\hline Spain and Portugal & Kraft Jacobs Suchard Iberia & Fresh cheese \\
\hline South Korea & Lotte Ham \& Milk Co., Ltd. & Dairy products \\
\hline Sweden & Milko & Dairy products \\
\hline USA & Stonyfield Farm & Yoghurt products \\
\hline
\end{tabular}


Table 3 Use of reuterin as an antimicrobial and fixation agent. MIC Minimal inhibitory concentration, $A U$ Reuterin activity unit defined as reciprocal of the highest dilution that did not permit growth of the indicator strain, $U 1 \mathrm{U}=5 \mu \mathrm{g}$ reuterin $/ \mathrm{ml}$

${ }^{\mathrm{a}}$ Calculation based on HPA dimer

${ }^{\mathrm{b}}$ Calculation based on HPA monomer

\begin{tabular}{|c|c|c|}
\hline Application & Concentration used & Reference \\
\hline $\begin{array}{l}\text { Bacteria, yeast, fungi, protozoa } \\
\text { Bacteria }\end{array}$ & 2-42 MIC & Dobrogosz et al. 1989 \\
\hline Salmonella typhimurium & $0.35-0.42^{\mathrm{a}}(0.7-0.84)^{\mathrm{b}} \mathrm{mM}$ & \\
\hline $\begin{array}{l}\text { Bacteria } \\
\text { Coliforms }\end{array}$ & $50-100 \mathrm{U} / \mathrm{g}$ ground beef & Daeschel 1989 \\
\hline $\begin{array}{l}\text { Protozoa } \\
\text { Trypanosoma brucei brucei }\end{array}$ & $<35^{\mathrm{a}}(70)^{\mathrm{b}} \mu \mathrm{M}$ & Yunmbam and Roberts 1992 \\
\hline $\begin{array}{l}\text { Vertebrates, mice } \\
\text { Protozoa in vertebrate }\end{array}$ & $\mathrm{LD}_{50} 1,500 \mathrm{U}(7.5 \mathrm{mg})$ & Yunmbam and Roberts 1993 \\
\hline Trypanosoma brucei brucei in mice & $300 \mathrm{U} / \mathrm{ml}(1.5 \mathrm{mg})$ & \\
\hline $\begin{array}{l}\text { Bacteria E. agglomerans, C. freudii, } \\
\text { K. pneumonia }\end{array}$ & $30 \mathrm{mM}$ & Barbirato et al. 1996 \\
\hline $\begin{array}{l}\text { Bacteria } \\
\text { Listeria monocytogenes } \\
\text { Escherichia coli } \mathrm{O} 157: \mathrm{H} 7\end{array}$ & $\begin{array}{l}50-250 \mathrm{AU} / \mathrm{g} \text { (cottage cheese) } \\
150 \mathrm{AU} / \mathrm{ml} \text { (UHT skim milk) } \\
100-500 \mathrm{AU} / \mathrm{g} \text { (meat surface) }\end{array}$ & $\begin{array}{l}\text { El-Ziney and Debevere 1998; } \\
\text { El Ziney et al. } 1999\end{array}$ \\
\hline $\begin{array}{r}\text { Bacteria } \\
\text { E. coli }\end{array}$ & $0-4 \mathrm{AU} / \mathrm{ml}$ & Rasch 2002 \\
\hline $\begin{array}{l}\text { Bacteria } \\
\text { E. coli; Pseudomonas aeruginosa, } \\
\text { Staphylococcus aureus, } \\
\text { Bacillus subtilis }\end{array}$ & $20-35 \mathrm{ppm}$ & $\begin{array}{l}\text { Chen et al. 2002; } \\
\text { Sung et al. 2002, } 2003\end{array}$ \\
\hline Fixation & $0.068 \mathrm{M}$ & \\
\hline
\end{tabular}

potential as a food preservative while also offering pharmaceutical benefits.

For the use of HPA, or reuterin, in food preparations $L$. reuteri, a probiotic strain, could be used to produce HPA in glycerol-containing water (Vollenweider et al. 2003). HPA concentrations reached by this method $(170 \mathrm{mM})$ are sufficient to achieve an inhibitory effect, and the supernatant can be used directly without further purification after production when food-grade culture medium is used (El-Ziney and Debevere 1998; El Ziney et al. 1999). For pharmaceutical application, a purified preparation of HPA would be needed (Chen et al. 2002). The purified extract should contain only solvents, which could be totally eliminated after purification (Vollenweider et al. 2003).

Mode of action and biological safety

Given the complexity of the HPA/reuterin system (Fig. 1) the question of which molecule (3-HPA, HPA-dimer or HPA-hydrate) is the active substance conferring antimicrobial activity arises. Dobrogosz (Dobrogosz and Lindgren 1988) made a first attempt to identify the active compound and proposed a carbohydrate-like structure for reuterin. A three-dimensional molecular model of the hemiacetal revealed a molecule that closely resembled a pentose such as D-ribose. It was then postulated that reuterin was able to compete with ribonucleotides for binding to the ribose recognition site of ribonucleotide reductase, the first enzyme involved in DNA synthesis. Thus, reuterin might inhibit the conversion of ribonucleotides into deoxyribonucleotides and hence exert its anti- microbial effect (Dobrogosz and Lindgren 1988; Talarico and Dobrogosz 1989). However, the observed inhibition of ribonucleotide reductase and thioredoxin by HPA might also be explained by another hypothesis involving the functional groups of the aldol 3-HPA. The hydroxyl and the aldehyde group might be responsible for the relative reactivity of the HPA monomer, which might cause it to react with unstable sulfhydryl groups of ribonucleotide reductase and thioredoxin (Schauenstein et al. 1977). Using quantitative ${ }^{13} \mathrm{NMR}$ Vollenweider et al. (2003) recently found that the composition of the HPA system was concentration dependent (Fig. 2).

At high concentrations $(4.9 \mathrm{M})$, the HPA system was predominantly composed of HPA-dimer along with unspecified HPA derivatives. At intermediate concentrations $(1.2 \mathrm{M})$ equal amounts of HPA-dimer and HPA-

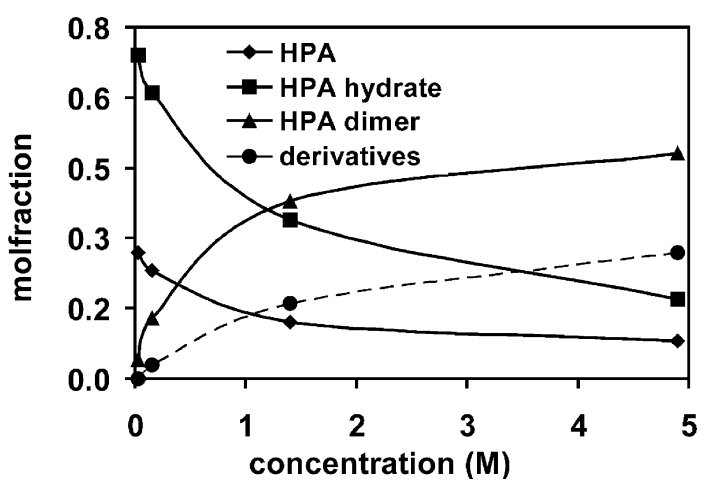

Fig. 2 Concentration-dependent distribution of the three forms of the HPA system in aqueous solution at $20^{\circ} \mathrm{C}$ measured by quantitative ${ }^{13} \mathrm{C}$ NMR (Vollenweider et al. 2003) 
hydrate were observed. At further dilution the fraction of dimer decreased rapidly and was replaced mainly by HPAhydrate. Equal amounts of HPA-dimer and 3-HPA were present at a concentration of $0.4 \mathrm{M}$. At the very low concentration of $0.03 \mathrm{M}$, the system was composed mainly of HPA-hydrate $(69 \%)$, followed by 3 -HPA $(27 \%)$ and HPA-dimer (4\%), whereas no derivatives could be detected. Further extrapolation of the curve suggests that the HPA system is likely to have a similar composition at concentrations below $0.03 \mathrm{M}$.

In some studies where HPA was used as an antimicrobial agent, reported molar concentrations were calculated using the molecular mass of the dimer form (Table 3). However, Fig. 2 clearly shows that HPA occurs mainly in its monomeric form at the concentrations used. This implies that the concentrations used in these studies were actually twice as high as those reported (Table 3 ).

The composition of HPA has also been reported to be $\mathrm{pH}$-dependent, forming mainly aldol dimer and polymers, or hemicacetal dimer, acetal trimer and polymers (Chen et al. 2002; Sung et al. 2003). All these molecules have aldehyde groups and have been reported to react with the amino groups in biological tissues (Sung et al. 2003). In contrast, in organic solutions the dimeric and polymeric forms seem to be predominant (Talarico and Dobrogosz 1989; Vollenweider et al. 2003). Hence, the composition of the HPA system is highly dynamic, which greatly affects its biological activity.

Detailed studies are needed to elucidate the mode of action of reuterin and the active component in vivo. A first step would be to accurately determine the concentration of HPA in aqueous solutions. Until now, no standardised unit is used to express the concentration of HPA (Table 3). The method for acrolein determination, using the acidcatalysed formation of a coloured complex between acrolein/HPA and tryptophan (Circle et al. 1945) has been adopted by several authors to accurately determine the molar concentration of HPA (Barbirato et al. 1996; Lüthi-Peng et al. 2002b; Sauvageot et al. 2000; Slininger et al. 1983; Smiley and Sobolov 1962; Vollenweider et al. 2003). Indeed, the use of molar concentrations would enable researchers to compare the anti-microbial activity of HPA in different biological systems as well as compare its activity to that of other molecules.

Another important consideration for biotechnological applications of HPA in foods is the accumulation of acrolein due to thermal dehydration (Nef 1904; Schütz and Radler 1984; Voisenet 1914a). Acrolein reacts with phenolic compounds, especially tannins present in alcoholic beverages, resulting in a bitter taste (Mills et al. 1954; Rentschler and Tanner 1951; Serjak et al. 1954). This spoilage of alcoholic beverages has been known since the eighteenth century, yet it remains a problem today and is an important topic of research (Claisse and LonvaudFunel 2001; Noble 1999; Sauvageot et al. 2000; Sponholz 1993). Acrolein is an $\alpha, \beta$-unsaturated aldehyde, which reacts with other molecules especially those containing sulfhydryl groups (e.g. proteins containing cysteine), causing the depletion of glutathione - one of the most important antioxidants - and/or general enzyme inhibition. Most human contact with acrolein occurs during exposure from incomplete combustion, such as that generated by cigarettes, automobiles, industrial processes, heating of animal and vegetable cooking oils, and burning (Ghilarducci and Tjeerdema 1995). Mucosal irritation has been observed at $1-2 \mathrm{mg} / \mathrm{m}^{3}$. Death in humans has occurred at $351 \mathrm{mg} / \mathrm{m}^{3}$. Fortunately, the odour perception of acrolein is $0.07 \mathrm{mg} / \mathrm{m}^{3}$ (Ghilarducci and Tjeerdema 1995).

HPA is stable at $4^{\circ} \mathrm{C}$, hence its use in foods such as milk products, which are stored at or below $4^{\circ} \mathrm{C}$ and are not heated, may be considered safe (El-Ziney and Debevere 1998; Vollenweider et al. 2003). However, at higher temperatures HPA becomes unstable and may react with other components present (Lüthi-Peng et al. 2002b; Sung et al. 2003). Therefore in heated food preparations containing HPA, the formation of acrolein is a risk requiring careful consideration. In-depth studies need to be carried out to demonstrate the safety of HPA in different foods (Ghilarducci and Tjeerdema 1995; Kehrer and Biswal 2000; Lüthi-Peng et al. 2002b; Sung et al. 2003).

HPA as a biotechnological precursor in the production of bulk chemicals

The value of HPA as a precursor in the production of useful industrial chemicals, for example plastics, was mentioned as early as 1950 (Hall and Stern 1950), and later for the production of acrylic acid. Slininger and colleagues (Slininger and Bothast 1985; Slininger et al. 1983) described the first attempt to produce HPA from renewable resources using modern biotechnology as an alternative for the production of major bulk chemicals.

\section{Acrolein}

Acrolein is produced chemically from propylene by direct catalytic oxidation, but the highest reported yield in the oxidation process is only $8 \%$ (Hess et al. 1978). The main uses of acrolein are as an intermediate in the synthesis of numerous chemicals, in particular acrylic acid and its lower alkyl esters, and DL-methionine, an essential amino acid. The most significant direct application of acrolein is as a herbicide to control the growth of aquatic plants. It kills plant cells by its reactivity with biological molecules and the destruction of cell membrane integrity (Ashton and Crafts 1981), as well as by its affinity for sulfhydryl groups, which causes the elimination of vital enzymatic pathways (WSSA 1983).

Acrolein is very polar and highly soluble in water. An aqueous acrolein solution has been reported to consist predominantly of HPA-hydrate, with about $92 \%$ under laboratory conditions, or even higher in river water (Bowmer and Higgins 1976; Bowmer and Sainty 1977; Ghilarducci and Tjeerdema 1995; O'Loughlin and Bowmer 1975). Other biological degradation products include 3-hydroxypropionic acid, allyl alcohol, acrylic acid, 
propionic acid, $\mathrm{HCO}_{3}{ }^{-}$, glyceric acid, 1,3-PDO, oxalic acid, propanol and butyric acid (Mao et al. 1994). All of these products are polar and highly soluble in water. Bioassays have shown that aqueous acrolein solutions become biocidally inactive after $120-180 \mathrm{~h}$, probably as a result of volatilisation of the compounds from water (Kissel et al. 1978; WHO 1992).

The formation of HPA from acrolein-containing solutions is reversible, as was mentioned previously for alcoholic beverages. Acrolein is accumulated by thermal dehydration during glycerol fermentation after the nearly complete disappearance of fermentable carbohydrates (ElZiney et al. 1998; Lüthi-Peng et al. 2002a; Mills et al. 1954; Sauvageot et al. 2000; Sobolov and Smiley 1960). Probiotic strains such as $L$. reuteri produce 3 -HPA in the bacterial supernatant in concentrations up to $170 \mathrm{mM}$ (Table 1). For use as a herbicide, concentrations of 6$10 \mathrm{mg} / \mathrm{l}(0.11-0.17 \mathrm{mM})$ acrolein are required. Thus, biotechnological fermentation of glycerol into 3-HPA followed by heating of the bacterial supernatant, thus producing acrolein, could provide an inexpensive alternative, requiring no further purification, to chemicallyproduced, high quality acrolein.

\section{Acrylic acid}

Acrylic acid is a petrochemical that is modified and polymerised into a broad range of versatile chemicals and resins for the production of viscosity modifiers and flocculants. Roughly three-quarters of its world production is converted directly into acrylate esters, the remainder being purified into glacial acrylic acid (Burridge 2002). The demand for acrylic acid has been rapidly increasing from a mere $400,000 \mathrm{t}$ in 1980 , to 3.4 million $\mathrm{t}$ in 2002 . This increase is mainly due to the increasing use of super absorber polymers in the hygiene industry. World capacity is predicted to rise to 4 million t/year by 2009 (Burridge 2002).

Acrylic acid is made via acrolein by gas-phase catalytic oxidation of propylene; it is a hydrocarbon gas, and a byproduct of oil refineries. The process is not very selective (Burridge 2002; Danner and Braun 1999). Several attempts have been made using different bacterial species to produce acrylic acid biotechnologically (Danner and Braun 1999; Danner et al. 1998). So far, acrylic acid has been produced by bacteria from acrylonitrile (Nagasawa et al. 1990; Narayanasamy et al. 1990) and from acrylamide (Nawaz et al. 1993, 1994), the highest yield being obtained from acrylonitrile $(390 \mathrm{~g} / \mathrm{l})$. Both the aforementioned substrates are secondary products that must be produced from other raw materials. Therefore, as suggested by several researchers, oxidation of HPA to acrylic acid may present a new alternative with great potential for the production of acrylic acid (Lüthi-Peng et al. 2002b; Slininger et al. 1983; Ulmer et al. 2002). However, no method has been described to date.

\section{1,3-PDO and hydroxypropionic acid}

1,3-PDO is used as a bulk chemical for polymer production, especially in the manufacture of the aromatic polyester PTT (polytrimethylene terephthalate) sold by Shell and DuPont under the trademarks CORTERRA and Sorona, respectively. This polymer exhibits properties desirable in carpets and textiles. Compared with other synthetic fibers like nylon, PTT fibers feel softer, dye more easily, retain vibrant colours longer, stretch and recover better, clean easily and dry quickly (http://www. eurekalert.org/pub_releasees/2003-02/d-cfc012903.php).

The demand for PTT is therefore expected to exceed 1 million metric tonnes by the year 2010 (http://www. search.shellchemicals.com). Currently 1,3-PDO is made using two different petroleum-based processes. Both methods use 3-HPA as an intermediate, which is hydrogenated with metal catalysts under high pressure (see section on petrochemically derived 3-HPA).

1,3-PDO is one of the oldest known fermentation products. It was first identified in 1881 by August Freund in a glycerol-fermenting mixed culture containing Clostridium pasteurianum (Freund 1881). Although the great potential of 1,3-PDO has long known been recognised, the expensive chemical synthesis has prevented its commercial production (Morris and Snider 1950). Over the past few years, extensive work has been done to increase the productivity and yield of biotechnological processes able to generate 1,3-PDO (Cameron et al.1998). The biological system developed by DuPont and Genencor, based on transformed E. coli, produces $129 \mathrm{~g} / 1$ 1,3-PDO after $74 \mathrm{~h}$, using sugar from corn and other crops (Emptage et al. 2003). However, the yield of $34 \%$ (g 1,3-PDO/g glucose) is quite low. 1,3-PDO can also be obtained by the fermentation of glycerol, with a theoretical yield of $67 \%$, since additional products need to be formed to generate sufficient $\mathrm{NADH}^{+}$for the reduction of 3-HPA to 1,3-PDO by enzymes (Wittlich 2001). Depending on the price of glycerol, the latter process could still be favoured over the former.

The biotechnological production of 3-HPA followed by its chemical reduction to 1,3-PDO offers great potential (Ulmer et al. 2002; Valerius et al. 1996). As stated above, L. reuteri can accumulate up to $12.5 \mathrm{~g} / 1(170 \mathrm{mM}) 3$-HPA with a yield of $0.68 \mathrm{~g} \mathrm{HPA} / \mathrm{g}$ glycerol, under unoptimised conditions (Lüthi-Peng et al. 2002b; Vollenweider et al. 2003). The theoretical yield would be $0.8 \mathrm{~g} 3$-HPA per gram glycerol (Slininger et al. 1983). In addition, the purity of 3-HPA produced in water containing glycerol reaches $87 \%$. The 3 -HPA thus generated could be easily hydrogenated using existing chemical methods, with yields of up to $99 \%$ (Brossmer and Arntz 2000; Etzkorn et al. 2000). Alternatively, in the presence of semicarbazide, Klebsiella was shown to accumulate up to $46 \mathrm{~g} / \mathrm{l}$ (621 mM) 3-HPA from glycerol (Vancauwenberge et al. 1990). Although perhaps offering great potential for the future, so far no method has been reported for the recovery of HPA from its semicarbazide form. 
3-Hydroxypropionic acid (3-HP), a molecule that has recently attracted considerable attention, can be chemically produced from sodium hydroxide and ethylene cyanohydrine (Read 2002). 3-HP will be used in the manufacture of coatings, adhesives, water-treatment chemicals and personal-care products. Cargill (http://www. cargill.com) and the United States Department of Energy will invest over US \$6 million to produce 3-HP biotechnologically (CEP 2003; Gokarn et al. 2002). Additionally, 3-HP is used as a substrate by specialised bacteria and transgenic plants to produce polyhydroxyalkanoates, a raw material for biodegradable plastics (Mittendorf et al. 1998). 3-HP has been described by several authors to be produced from 3-HPA during glycerol fermentation leading to equal molar concentrations of 1,3-PDO and 3-HP (Slininger et al. 1983; Sobolov and Smiley 1960; Talarico et al. 1988).

\section{Polymers}

The last two decades have shown a steady increase in polymer research. In 1980, less than 50 new patents concerned polymers, while in 2001 over 1,100 patents on polymers were published. Of these patents, only $25-30 \%$ dealt with petrochemical polymers; the vast majority concerned biopolymers, both starch polymers and natural polyesters. Today about 200 million tonnes are used compared with about 60 million tonnes in 1980. This demand is predicted to increase to about 260 million tonnes by 2010 (Lörcks 2000). As already discussed, polymers can be generated from HPA via 1,3-PDO; however, HPA can also transform itself into polymeric derivatives and resins (Fig. 3) (Hall and Stern 1950; Nielsen et al. 1981; Sung et al. 2003).
To date, no study has addressed the issues of controlled production or the various uses of polymeric derivatives. In theory, careful manipulation of experimental conditions such as concentration, solvent, $\mathrm{pH}$, and temperature may provide an important tool to control the synthesis of specific polymers.

\section{Economical considerations}

The petrochemical industry is still one of the world's most important industries, with a steadily rising demand for its products. Current estimates predict a 5-fold increase in demand for chemicals and consumables by 2020, and another 5-fold increase between then and the year 2050 (Inverizon International 1998). The availability of petrochemicals is largely determined by political forces, and the source of raw material is limited. Consequently, the price of petroleum has steadily increased since 1970 from about US \$3/barrel to US \$30/barrel today.

Renewable resources from plants, as well as agricultural wastes transformed by bacteria, can provide many of the same chemical building blocks as the petrochemical industry, as well as some new ones. The costs of plantderived materials are largely dependent on weather conditions. Of great importance is the ecological impact. Plant-derived materials may lead to increased monoculture in agriculture and increased plant production may only be possible with genetically modified plants. However, it is expected that the use of fossil fuels will stabilise at approximately current levels and that the increasing demand for chemicals will be met through bio-transformation and biotechnological engineering using renewable resources (de Boer and Schmidt-Dannert 2003; Inverizon International 1998). Already, the increasing number of

$\begin{array}{ll} & \\ \text { acidic conditions } & \mathrm{CH}_{2}-\mathrm{CH}_{2}^{-}{ }^{\mathrm{OH}} \\ \mathrm{CH} \\ \mathrm{OH}\end{array}$

acidic and basic conditions

monomer

cyclic dimer

hemiacetal dimer

acetal trimer

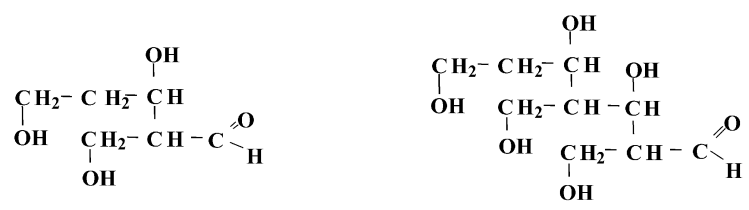

aldol dimer

aldol trimer

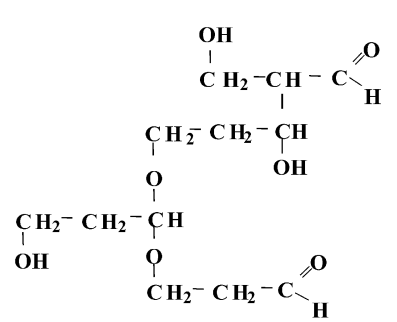

acetal tetramer

Fig. 3 Different forms of 3-HPA in acidic and/or basic aqueous solutions; adapted from Sung et al. (2003) 
patents in this area is indicative of the increasing trend in this industry.

As presented above, 3-HPA can be produced by bacteria by the fermentation of glycerol. Theoretically, the development of strains using fermentable carbohydrates such as glucose as substrate, which cost 3-5 times less than glycerol, is desirable. The example of 1,3-PDO shows the feasibility of this approach. However, since glucose can also be transformed into a wide range of products other than those of interest, the resulting yield and purity of the final product is low. The theoretical yield of the one-step enzymatic transformation process from glycerol to 3-HPA is $1 \mathrm{~mol} \mathrm{HPA} / \mathrm{mol}$ glycerol. Production can be accomplished in water, into which 3-HPA is secreted. This results in increased purity and yield. Bacterial strains using a non-cobamide-dependent glycerol dehydratase may be a valuable tool for decreasing the cost of 3-HPA production (Zeng and Biebl 2002).

Glycerol is formed as a side-product during the production of soap, fatty acids, and biodiesel. Experts predict a tremendous increase in the annual production of biodiesel from 2.7 million tonnes today to about 7 9 million tonnes by 2010 (Widmer and Müller 2003). Roughly $10 \%$ of this production will be in the form of glycerol. The expansion of the biodiesel market will therefore lead to an increased glycerol production, concomitant with a decrease in price (Fig. 4).

An additional source for glycerol may be the increased production during ethanol fermentation without changing the ethanol yield. As cited by Zeng and Biebl (2002) High Plains Corporation (York, Neb.) plans to recover glycerol (99.7\%) from ethanol fermentation broth by a novel filtration process at costs below US $\$ 300-400 / t$, which is well below the cost of glycerol on the market (Fig. 4). Production of $600,000 \mathrm{t} / \mathrm{year}$ would be possible, which would have a significant economic impact on the glycerol market and price.

The use of 3-HPA as a preservation agent in food or as a disinfectant in the pharmaceutical field is not much affected by these economic considerations. However, as a potential source of bulk chemicals, the price of

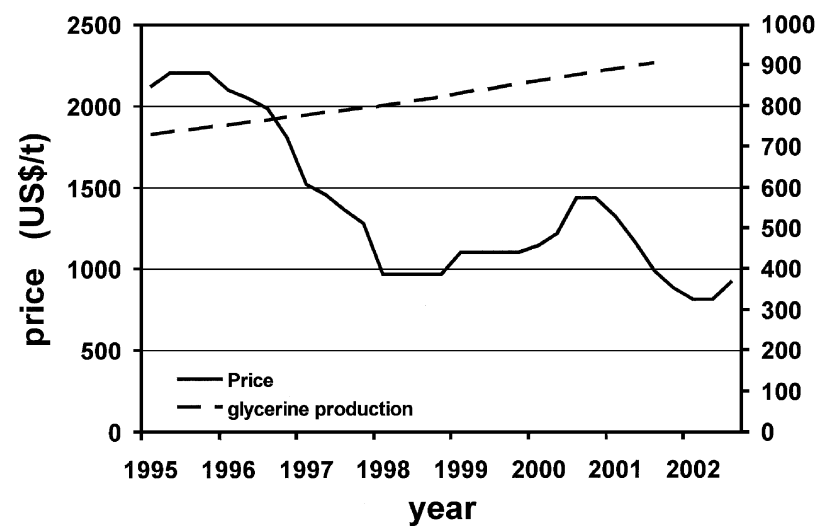

Fig. 4 Development of glycerol price and production since 1995. The price is for refined glycerol. (Procter \& Gamble Chemicals, 2003 personal communication; HB International, 2003 personal communication)
Table 4 Current price of chemicals. PTT Polytrimethylene terephthalate

\begin{tabular}{ll}
\hline Chemical & Price US \$/metric ton (2003) \\
\hline Acrolein & $1.400^{\mathrm{a}}$ \\
Acrylic acid & $1.345-1.500^{\mathrm{b}}$ \\
1,3-Propanediol & n.i. $\mathrm{a}^{\mathrm{c}}$ \\
PTT & $1.000^{\mathrm{d}}$ to $<1.500^{\mathrm{e}}$ \\
\hline
\end{tabular}

${ }^{\mathrm{a}}$ Market research, ${ }^{\mathrm{b}}$ Celanese AG, ${ }^{\mathrm{c}}$ No information available, ${ }^{\mathrm{d}}$ Zeng and Biebl (2002), ${ }^{\mathrm{e}}$ Schoenberger (2003)

biotechnologically produced 3-HPA and thus of glycerol will be of major importance to the viability of this industry, as it has to compete with the chemical industry (Table 4).

\section{HPA biotechnology—conclusions and future trends}

The HPA system is composed of different derivatives that create the basis for its outstanding chemical properties. Biotechnologically produced HPA may find applications in health care, in the food industry, and in the chemical industry (Fig. 5).

Due to its broad antimicrobial activity, the 3-HPAproducing bacterium $L$. reuteri is used as a probiotic strain in human and animal diets to positively influence the microbial balance in the intestine. $L$. reuteri was shown to produce two other molecules with antimicrobial activity: reutericyclin (Gänzle and Vogel 2003; Holtzel et al. 2000) and reutericin (Kabuki et al. 1997; Toba et al. 1991). However, the production of both of these molecules in vivo has not yet been tested. The interaction of HPA with reutericyclin and reutericin warrants further research because these molecules may play a synergistic role in the protection of $L$. reuteri, and therefore of the host, against pathogenic bacteria.

The "antibiotic" properties of reuterin are known to inhibit the growth of several human pathogens, including protozoa, viruses, and bacteria (Dobrogosz and Lindgren 1988), which make it attractive for use as a food

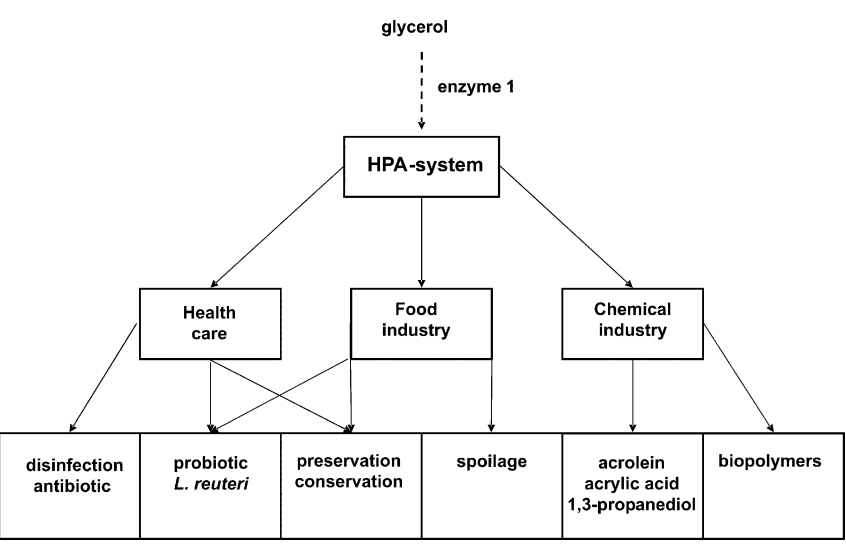

Fig. 5 Potential applications of biotechnologically produced HPA in industry 
preservation and conservation agent (Fig. 5). HPA is produced by a probiotic strain and is excreted into the medium. In the future, productivity may be improved by optimising the fermentation strategy, culture conditions, and purification strategy, as well as by genetic engineering. An HPA-enriched medium could be used directly for applications in foods (El-Ziney and Debevere 1998; El Ziney et al. 1999); alternatively HPA may also be purified from bacterial supernatants by existing methods if necessary (Vollenweider et al. 2003).

In combination with other antimicrobial molecules, such as bacteriocins, HPA may also reveal synergistic effects that could help to overcome the increasing resistance of bacteria against antibiotics. HPA was also reported to be a useful chemical in the fixation of biological tissues, with equal fixation possibilities but less cytotoxic effects than glutaraldehyde, a chemical frequently used for this purpose (Sung et al. 2002, 2003). The proven low cytotoxic effect of HPA makes it an ideal molecule for future use in biological systems. However, HPA has been shown to react with other molecules in complex media, particularly when heated (Lüthi-Peng et al. 2002b; Sung et al. 2002, 2003). Under certain conditions, acrolein, a very toxic aldehyde, may be formed, leading to food spoilage (Lüthi-Peng et al. 2002b; Mills et al. 1954; Reymolds et al. 1939; Sauvageot et al. 2000; Serjak et al. 1954). Time-temperature combinations, physicochemical characteristics and the chemical composition of foods may affect these reactions, but very little information is available on this important issue. Therefore heat-treated foods containing HPA should be carefully surveyed, and detailed studies are needed to elucidate the mode of action of HPA in biological systems. Finally, HPA can be used as a precursor in enzymatic and chemical reactions for the preparation of bulk chemicals such as acrolein, acrylic acid, 1,3-PDO and in the formation of biopolymers. However, large-scale synthesis of these HPA-derived compounds will also require optimisation of biotechnological production and purification in order to produce HPA with high yields and low costs.

We may thus anticipate that, after the optimisation of its biotechnological production, HPA will probably achieve a biotechnological importance similar to that of 1,3-PDO.

Acknowledgements We thank Prof. Dr. Puhan for critical advice. We thank Prof. Hsing-Wen Sung, Mr. Donald B. Appleby (Procter \& Gamble Chemicals), and Mr. Valéry Desroches (HB International S.A.), for kindly providing data for the figures presented in this work. We thank Mr. Heinz Trogemann (Stockhausen GmbH \& Co. $\mathrm{KG}$ ) and Mrs. Albrecht (Celanese AG) for providing information on the price of acrylic acid, and Joseph W. Carroll (DuPont Co.) for helpful discussions. The authors would like to offer special thanks to Annemieke Ijpenberg and Janice Sych for critical review.

\section{References}

Abeles RH, Brownstein AM, Randles CH (1960) $\beta$-Hydroxypropionaldehyde, an intermediate in the formation of 1,3propanediol by Aerobacter aerogenes. Biochim Biophys Acta 41:530-531

Arntz D, Wiegand N (1991) Method of preparing 1,3-propanediol. US Patent 5015789

Ashton FM, Crafts AS (1981) Mode of action of herbicides. Wiley, New York

Axelsson L, Chung TC, Dobrogosz WJ, Lindgren SE (1988) Production of a broad-spectrum antimicrobial substance produced by Lactobacillus reuteri. Microb Ecol Health Dis 2:131-136

Barbirato F, Grivet JP, Soucaille P, Bories A (1996) 3-Hydroxypropionaldehyde, an inhibitory metabolite of glycerol fermentation to 1,3-propanediol by enterobacterial species. Appl Environ Microbiol 62:1448-1451

Berzelius J (1839) Lehrbuch der Chemie. Dresden und Leipzig

Biebl H, Menzel K, Zeng AP, Deckwer WD (1999) Microbial production of 1,3-propanediol. Appl Microbiol Biotechnol 52:289-297

Boer AL de, Schmidt-Dannert C (2003) Recent efforts in engineering microbial cells to produce new chemical compounds. Curr Opin Chem Biol 7:273-278

Bowmer KH, Higgins ML (1976) Some aspects of the persistence and fate of acrolein herbicide in water. Arch Environ Contam Toxicol 5:87-96

Bowmer KH, Sainty E (1977) Management of aquatic plants with acrolein. J Aquat Plant Manage 15:40-46

Brossmer C, Arntz D (2000) Process for the production of 1,3propanediol. US Patent 6140543

Burridge A (2002) Product profile: acrylic acid. European Chemical News 16-22 September, Reed Business Information

Cameron DC, Altaras NE, Hoffman ML, Shaw AJ (1998) Metabolic engineering of propanediol pathways. Biotechnol Prog 14:116 125

Casas IA, Dobrogosz WJ (1997) Lactobacillus reuteri: overview of a new probiotic for humans and animals. Microbiol Ther 26:221-231

Casas IA, Dobrogosz WJ (2000) Validation of the probiotic concept: Lactobacillus reuteri confers broad-spectrum protection against disease in humans and animals. Microb Ecol Health Dis 12:285

CEP (2003) Engineering 1,3-carbon molecules. AIChE, New York, www.cepmagazine.org. Cited 14 February 2003

Chen CN, Sung HW, Liang HF, Chang WH (2002) Feasibility study using a natural compound (reuterin) produced by Lactobacillus reuteri in sterilizing and crosslinking biological tissues. J Biomed Mater Res 61:360-369

Chevreul ME (1823) In: Levrault (ed) Recherches sur les corps gras d'origine animale. Paris

Circle SJ, Stone L, Boruff CS (1945) Acrolein determination by means of tryptophan. Ind Eng Chem 17:259-262

Claisse O, Lonvaud-Funel A (2001) Primers and a specific DNA probe for detecting lactic acid bacteria producing 3-hydroxypropionaldehyde from glycerol in spoiled ciders. J Food Prot 64:833-837

Daeschel MA (1989) Antimicrobial substances from lactic acid bacteria for use as food preservatives. Food Technol 43:164 167

Daniel R, Bobik TA, Gottschalk G (1999) Biochemistry of coenzyme $\mathrm{B}_{12}$-dependent glycerol and diol dehydratases and organization of the encoding genes. FEMS Microbiol Rev 22:553-566

Danner H, Braun R (1999) Biotechnology for the production of commodity chemicals from biomass. Chem Soc Rev 28:395405

Danner H, Ürmös M, Gartner M, Braun R (1998) Biotechnological production of acrylic acid out of biomass. Appl Biochem Biotechnol 70-72:887-894

Dobrogosz WJ, Lindgren SE (1988) Antibiotic reuterin. US Patent PCT/US88/01423 
Dobrogosz WJ, Casas IA, Pagano GA, Sjöberg B-M, Talarico TL, Karlsson M (1989) Lactobacillus reuteri and the enteric microbiota. In: Grubb R, Midtvedt T, Norin E (eds) The regulatory and protective role of the normal microflora. MacMillan, London, pp 283-292

El-Ziney MG, Debevere J (1998) The effect of reuterin on Listeria monocytogenes and Escherichia coli $\mathrm{O} 157: \mathrm{H} 7$ in milk and cottage cheese. J Food Prot 61:1275-1280

El-Ziney MG, Arneborg N, Uyttendaele M, Debevere J, Jakobsen M (1998) Characterization of growth and metabolite production of Lactobacillus reuteri during glucose/glycerol cofermentation in batch and continuous cultures. Biotechnol Lett 20:913-916

El Ziney MG, van den Tempel T, Debevere J, Jakobsen M (1999) Application of reuterin produced by Lactobacillus reuteri 12002 for meat decontamination and preservation. J Food Prot 62:257-261

Emptage MH, Sharon L, Laffend LA, Pucci JP, Whited G (2003) Process for the biological production of 1,3-propanediol with high titer. US Patent 6514733

Etzkorn WG, Brockwell JL, Young MA, Maher JM, Warren BK (2000) Production of 1,3-propanediol from 3-hydroxypropionaldehyde. US Patent 6166263

Freund A (1881) Über die Bildung und Darstellung von Trimethylenalkohol aus Glycerin. Monatsh Chem 2:636-641

Gänzle MG, Vogel RF (2003) Studies on the mode of action of reutericyclin. Appl Environ Microbiol 69:1305-1307

Geoffroy CJ (1742) Method of making soap-lees and hard soap, for medicinal uses. Phil Trans R Soc London 42:71-77

Ghilarducci DP, Tjeerdema RS (1995) Fate and effects of acrolein. Rev Environ Contam Toxicol 95-146

Gokarn RR, Selifonova OV, Jessen HJ, Gort SJ, Selmer T, Buckel W (2002) 3-Hydroxypropionic acid and other organic compounds. Canadian Patent 2429039

Hall RH, Stern ES (1950) Acid-catalysed hydration of acrylaldehyde: kinetics of the reaction and isolation of $\beta$-hydroxypropaldehyde. J Chem Soc 490-498

Hess LG, Kurtz AN, Stanton DB (1978) Acrolein and derivatives. In: Grayson M, Eckroth D (eds) Kirk-Othmer encyclopedia of chemical technology. Wiley, New York, pp 277-297

Holtzel A, Gänzle MG, Nicholson GJ, Hammes WP, Jung G (2000) The first low molecular weight antibiotic from lactic acid bacteria: reutericyclin, a new tetramic acid. Angew Chem Int Ed Eng 39:2766-2768

Humphreys FB (1924) Formation of acrolein from glycerol by $B$. welchii. J Inf Dis 35:282-290

Inverizon International (1998) Technology Roadmap for Plant/CropBased Renewable Resources 2020. Inverizon International, Chesterfield, Mo., http://www.oit.doe.gov/agriculture/pdfs/ technology roadmap.pdf

Kabuki T, Saito T, Kawai Y, Uemura J, Itoh T (1997) Production, purification and characterization of reutericin 6 , a bacteriocin with lytic activity produced by Lactobacillus reuteri LA6. Int J Food Microbiol 34:145-156

Kehrer JS, Biswal SS (2000) The molecular effects of acrolein. Toxicol Sci 57:6-15

Kissel CL, Brady JL, Guerra AM, Pau JK, Rockie BA, Caserio FF Jr (1978) Analysis of acrolein in aged aqueous media. Comparison of various analytical methods with bioassays. J Agric Food Chem 26:1338-1343

Klantschitsch T, Spillmann H, Puhan Z (1996) Lactobacillus reuteri: Ein milchwirtschaftlicher Neuling. DMZ Lebensm-Ind Milchwirtsch 17:790-797

Knifton JF, Slaugh LH, Weider PR, James TG, Powell JB, Allen KD, Williams TS (2003) One step process for preparing a 1,3diol. US Patent 6518466

Lörcks J (2000) Biologisch abbaubare Werkstoffe. Fachagentur Nachwachsende Rohstoffe, Gülzow, Germany

Lüthi-Peng Q, Dileme FB, Puhan Z (2002a) Effect of glucose on glycerol bioconversion by Lactobacillus reuteri. Appl Microbiol Biotechnol 59:289-296
Lüthi-Peng Q, Schärer S, Puhan Z (2002b) Production and stability of 3-hydroxypropionaldehyde in Lactobacillus reuteri. Appl Microbiol Biotechnol 60:73-80

Mao J, Doane R, Kovacs MF Jr (1994) Separation of acrolein and its possible metabolites using different modes of high performance liquid chromatography. J Liquid Chrom 17:1811-1819

Matagrin A (1925) Chevreul et la bougie stéarique. Ind Chim 12:400-402

Mickelson MN, Werkman CH (1940) The dissimilation of glycerol by coli-aerogenes intermediates. J Bacteriol 39:709-715

Mills E, Baugh WD, Conner HA (1954) Studies on the formation of acrolein in distillery mashes. Appl Microbiol 2:9-13

Mittendorf V, Robertson EJ, Leech RM, Kruger N, Steinbüchel A, Poirier Y (1998) Synthesis of medium-chain-length polyhydroxyalkanoates in Arabidopsis thaliana using intermediates of peroxisomal fatty acid beta-oxidation. Proc Natl Acad Sci USA 95:13397-13402

Morris RC, Snider AV (1950) Polymers of trimethylene glycol. US Patent 2520733

Mukai T, Asasaka T, Sato E, Mori K, Matsumoto M, Ohori H (2002) Inhibition of binding of Helicobacter pylori to the glycolipid receptors by probiotic Lactobacillus reuteri. FEMS Immuno Med Microbiol 32:105-110

Nagasawa T, Nakamura T, Yamada H (1990) Production of acrylic acid and methacrylic acid using Rhodococcus rhodochrous J1 nitrilase. Appl Microbiol Biotechnol 34:322-324

Narayanasamy K, Shukla S, Parekh LJ (1990) Utilization of acrylonitrile by bacteria isolated from petrochemical waste waters. Indian J Exp Biol 28:968-971

Nawaz MS, Franklin W, Cerniglia CE (1993) Degradation of acrylamide by immobilized cells of a Pseudomonas sp. and Xanthomonas maltophilia. Can J Microbiol 39:207-212

Nawaz MS, Franklin W, Cerniglia CE (1994) Degradation of aliphatic amide mixture by immobilized and nonimmobilized cells of Pseudomonas sp. Environ Sci Technol 28:1106-1109

Nef JU (1904) Dissociationsvorgänge in der Glycol-Glycerinreihe. Ann Chem 335:191-245

Nielsen AT, Moore DW, Schuetze Jr (1981) A ${ }^{13} \mathrm{C}$ and ${ }^{1} \mathrm{H}$ NMR study of formaldehyde reactions with acetaldehyde and acrolein. Synthesis of 2-(hydroxymethyl)-1,3-propanediol. Pol J Chem 55:1393-1403

Noble A (1999) Why do wines taste bitter and feel astringent? In: Waterhouse AL, Ebeler SE (eds) Chemistry of wine flavor. Am Chem Soc, Washington, D.C., pp 156-165

O'Loughlin, Bowmer KH (1975) Dilution and decay of aquatic herbicides in flowing channels. J Hydrol 26:217-235

Otsuka K (2003) Studies on the mechanism of glycerol metabolism by microbes. Bull Res Inst Ferment Yamanashi Univ 5:1-58

Pasteur L (1858a) Nouvelles recherches sur la fermentation alcoolique. C R Acad Sci XLVII:224

Pasteur L (1858b) Production constante de glycérine dans la fermentation alcoolique. C R Acad Sci XLVI:857

Pasteur L (1866) Etudes sur le vin, ses maladies; causes qui les provoquent, procédées nouveaux pour le conserver et pour le vieillir. Masson, Paris

Pressman D, Lucas HJ (1942) Hydration of unsaturated compounds XI. Acrolein and acrylic acid. J Am Chem Soc 64:1953-1957

Rasch M (2002) The influence of temperature, salt and $\mathrm{pH}$ on the inhibitory effect of reuterin on Escherichia coli. Int J Food Microbiol 72:225-231

Read RR (2002) $\beta$-Hydroxypropionic acid. Org Synth 1:321

Redtenbacher J (1843) Über die Zerlegungsprodukte des Glycerinoxydes durch trockene Destillation. Ann Chem Pharm 47:113-148

Redtenbacher J (1846) Über eine neue Entstehungsweise der Metacetonsäure. Ann Chem Pharm 57:170

Reid G (1999) The scientific basis for probiotic strains of Lactobacillus. Appl Environ Microbiol 65:3763-3766

Rentschler H, Tanner H (1951) Das Bitterwerden der Rotweine. Mitt Lebensm-Unters Hyg 42:463-475 
Reymolds H, Hoehn WM, Werkman CH (1939) Occurrence of acrolein as an intermediate during the fermentation of glycerol by the coli-aerogenes bacteria. Iowa State Coll J Sci 13:277

Sauvageot N, Gouffi K, Laplace JM, Auffray Y (2000) Glycerol metabolism in Lactobacillus collinoides: production of 3hydroxypropionaldehyde, a precursor of acrolein. Int J Food Microbiol 55:167-170

Schauenstein E, Esterbauer H, Zollner H (1977) Saturated aldehydes. In: Schauenstein E, Esterbauer H, Zollner H (eds) Aldehydes in biological systems their natural occurrence and biological activities. Pion, London, pp 9-24

Scheele CW (1931) On the peculiar saccharine principle in expressed oils and fats. The collected papers of CW Scheele $255-258$

Schoenberger CR (2003) Greenhouse effect. Forbes Magazine (http://www.forbes.com/forbes/2003/0203/054_print.html)

Schütz H, Radler F (1984) Anaerobic reduction of glycerol to propanediol-1.3 by Lactobacillus brevis and Lactobacillus buchneri. Syst Appl Microbiol 5:169-178

Serjak WC, Day WH, Van Lanen JM, Boruff CS (1954) Acrolein production by bacteria found in distillery grain mashes. Appl Microbiol 2:14-20

Shornikova AV, Casas IA, Isolauri E, Mykkanen H, Vesikari T (1997) Lactobacillus reuteri as a therapeutic agent in acute diarrhea in young children. J Pediatr Gastroenterol Nutr 24:399-404

Slininger PJ, Bothast RJ (1985) Optimizing aerobic conversion of glycerol to 3-hydroxypropionaldehyde. Appl Environ Microbiol 50:1444-1450

Slininger PJ, Bothast RJ, Smiley KL (1983) Production of 3hydroxypropionaldehyde from glycerol. Appl Environ Microbiol 46:62-67

Smiley KL, Sobolov M (1962) A cobamide-requiring glycerol dehydrase from an acrolein-forming Lactobacillus. Arch Biochem Biophys 97:538-543

Sobolov M, Smiley KL (1960) Metabolism of glycerol by an acrolein-forming Lactobacillus. J Bacteriol 79:261-266

Sponholz W-R (1993) Wine spoilage by microorganisms. In: Fleet GH (ed) Wine microbiology and biotechnology. Harwood, Chur, pp 395-420

Stepanow A, Schtschukin M (1927) Über die Aldolkondensation von Formaldehyde und Acetaldehyde. Chem Zentralbl D 1167

Sung HW, Chen CN, Chang Y, Liang HF (2002) Biocompatibility study of biological tissues fixed by a natural compound (reuterin) produced by Lactobacillus reuteri. Biomaterials 23:3203-3214

Sung HW, Chen CN, Liang HF, Hong MH (2003) A natural compound (reuterin) produced by Lactobacillus reuteri for biological-tissue fixation. Biomaterials 24:1335-1347

Talarico TL, Dobrogosz WJ (1989) Chemical characterization of an antimicrobial substance produced by Lactobacillus reuteri. Antimicrob Agents Chemother 33:674-679

Talarico TL, Casas IA, Chung TC, Dobrogosz WJ (1988) Production and isolation of reuterin, a growth inhibitor produced by Lactobacillus reuteri. Antimicrob Agents Chemother 32:1854-1858

Tannock GW (1999) Probiotics: a critical review. Horizon, Wymondham
Thiman KV (1955) The life of bacteria their growth, metabolism, and relationships. MacMillan, New York

Toba T, Samant SK, Yoshioka E, Itoh T (1991) Reutericin-6, a new bacteriocin produced by Lactobacillus reuteri La-6. Lett Appl Microbiol 13:281-286

Toraya T (2000) Radical catalysis of B12 enzymes: structure, mechanism, inactivation, and reactivation of diol and glycerol dehydratases. Cell Mol Life Sci 57:106-127

Ulmer C, Deckwer W-D, Zeng A-P (2002) Zweistufiger Prozess zur Herstellung von 1,3-Propandiol und 3-Hydroxypropionaldehyde aus Glycerin. Chem Ing Tech 74:674

Valerius G, Zhu X, Hofmann H, Arntz D, Haas T (1996) Modelling of a trickle-bed reactor 2. The hydrogenation of 3-hydroxypropanal to 1,3-propanediol. Chem Eng Proc 35:11-19

Valeur N, Engel P, Ladefoged K (2002) Immunomodulation in the human GI tract by the probiotic Lactobacillus reuteri (ATCC 55730/SD2112). Am J Gastroent 97:S76

Vancauwenberge JE, Slininger PJ, Bothast RJ (1990) Bacterial conversion of glycerol to beta-hydroxypropionaldehyde. Appl Environ Microbiol 56:329-332

Voisenet ME (1910) Formation d'acroléine dans la maladie de l'amertume des vins. C R Acad Sci 150:1614-1616

Voisenet ME (1914a) Sur un ferment, contenu dans les eaux, agent de déshydratation de la glycérine. C R Acad Sci 158:195-197

Voisenet ME (1914b) Sur un ferment, contenu dans les eaux, agent de déshydratation de la glycérine. Ann Inst Pasteur 28:807-818

Vollenweider S, Grassi G, König I, Puhan Z (2003) Purification and structural characterization of 3-hydroxypropionaldehyde and its derivatives. J Agric Food Chem 51:3287-3293

WHO (1992) Acrolein. Environ Health Crit 127

Widmer A, Müller A (2003) Glycerin überschwemmt Europa. Chem Rundschau 10:4-6

Wittlich P (2001) Biotechnische Herstellung von 1,3-Propandiol aus Glycerin mit immobilisierten Zellen von Clostridium butyricum NRRL B-1024 und thermophilen Mikroorganismen. Dissertation, Technische Universität Braunschweig, Germany

Wolf BW, Garleb KA, Ataya DG, Casas IA (1995) Safety and tolerance of Lactobacillus reuteri in healthy adult male subjects. Microb Ecol Health Dis 8:41-50

Wolf BW, Wheeler KB, Ataya DG, Garleb KA (1998) Safety and tolerance of Lactobacillus reuteri supplementation to a population infected with the human immunodeficiency virus. Food Chem Toxicol 36:1085-1094

WSSA (1983) Herbicide Handbook of the Weed Science Society of America

Yunmbam MK, Roberts JF (1992) The in vitro efficacy of reuterin on the culture and bloodstream forms of Trypanosoma brucei brucei. Comp Biochem Physiol C 101:235-238

Yunmbam MK, Roberts JF (1993) In vivo evaluation of reuterin and its combinations with suramin, melarsoprol, DL-alpha-difluoromethylornithine and bleomycin in mice infected with Trypanosoma brucei brucei. Comp Biochem Physiol C 105:521524

Zeng AP, Biebl H (2002) Bulk chemicals from biotechnology: the case of 1,3-propanediol production and the new trends. Adv Biochem Eng Biotechnol 74:239-259 